\title{
Assessment of Estradiol, Progesterone and Lipid Profile among Breast Cancer Patients in Ethiopia: Hospital-based Comparative Cross-Sectional Study
}

\section{Etagegn Tadesse}

Addis Ababa University College of Health Sciences

\section{Daniel Seifu}

Addis Ababa University College of Health Sciences

\section{Menakath Menon}

Addis Ababa University Faculty of Medicine: Addis Ababa University School of Medicine

Wondmagegnehu Tigeneh

Addis Ababa University Faculty of Medicine: Addis Ababa University School of Medicine

\section{Teka Obsa}

Haramaya University

\section{Bikila Neges}

Ethiopian Health and Nutrition Research Institute: Ethiopian Public Health Institute

Mohammed Mehdi ( $\nabla$ mohammed.mehdi@aau.edu.et)

Addis Ababa University College of Health Sciences https://orcid.org/0000-0003-2114-9325

\section{Research article}

Keywords: Breast cancer, Estradiol, Lipid profile, Progesterone

Posted Date: October 19th, 2021

DOI: https://doi.org/10.21203/rs.3.rs-966771/v1

License: (c) (i) This work is licensed under a Creative Commons Attribution 4.0 International License. Read Full License 


\section{Abstract \\ Background}

Breast cancer is the most often diagnosed type of cancer and the leading cause of death worldwide. Estrogen, also known as estradiol, influences progesterone metabolism and modifies lipid metabolism. Thus, steroid hormone and lipid profile levels for breast cancer patients must be evaluated. However, this has yet to be explored and used for therapy in Ethiopia. As a result, the present study at Tikur Anbessa Specialized Hospital attempted to assess serum estrogen, progesterone, and lipid profile levels in breast cancer patients and healthy controls.

\section{Methods}

A hospital-based comparative cross-sectional study was conducted on a total of 80 participants ( 40 newly diagnosed breast cancer patients and 40 healthy control females). A convenient sampling method was used to recruit the study participants. Steroid hormones and lipid profile were determined using immunoassays and an enzymatic colorimetric technique, respectively. SPSS version 20.0 was used for statistical analysis, and p-values of 0.05 were considered statistically significant.

\section{Results}

When compared to healthy controls, the mean serum progesterone, TC, and HDL-C levels in breast cancer patients were considerably lower, while estradiol, TG, and LDL-C levels were insignificantly higher.

\section{Conclusions}

Breast cancer may be to blame for changes in progesterone, estradiol, and lipid profile levels, which can lead to secondary problems.

\section{Introduction}

Breast cancer is the most commonly diagnosed cancer and the major cause of death worldwide, accounting for 2.1 million new cases and 626,679 deaths from total cancer in $2018^{1}$. It is the most common malignancy among women throughout the industrialized world ${ }^{2}$. Many cancers have a two to threefold higher incidence rate in developed countries than in developing countries 1 . However, $60 \%$ of deaths are estimated to occur in developing countries, owing to the majority of cases being diagnosed at later stages due to limited resources and infrastructure, which challenges the goal of improving breast cancer outcomes through early detection, diagnosis, and treatment ${ }^{3,4}$. 
Breast cancer is the most commonly diagnosed cancer and the major cause of death worldwide and accounts for 2.1 million new cases and 626,679 deaths of total cancer in $2018^{1}$. It is the most common malignancy among women throughout the industrialized world ${ }^{2}$. In developed countries, the incidence rates of many cancers are generally two to three folds higher than in developing countries ${ }^{1}$. However, $60 \%$ of the deaths are estimated to occur in developing countries, because the majority of the cases are diagnosed in later stages due to limited resources and infrastructure that challenges the goal of improving breast cancer outcomes by early detection, diagnosis, and treatment ${ }^{3,4}$.

In Africa, the estimated number of new cases of breast cancer were 1.06 million in 2018 ( $5.8 \%$ of the total) and the number of deaths was 693,000 (7.3\% of the total) ${ }^{1}$. In Sub-Saharan Africa, 94,000 women developed breast cancer, out which 48,000 died in $2012^{5}$. specific in Ethiopia, the prevalence of breast cancer was $20.8 \%$ from 1997 to 2012 among the total number of all new cancer cases registered in Tikur Anbessa Specialized Hospital ${ }^{6}$. Based on a recent report by Hadgu et al., the annual incidence and mortality rate of breast cancer accounts for $34 \%$ of female cancer cases, followed by cervical cancer, which accounts for $16 \%{ }^{7}$.

The growth of many breast tumors is estrogen-dependent and approximately $70-80 \%$ of all breast cancers are hormone-sensitive ${ }^{8}$. Malignant cells metabolize lipids differently from the normal cells and the change of lipid profile levels may be the result of abnormal lipid metabolism, which is associated with tumor pathogenesis and tumor-host interactions ${ }^{9}$. The enhancement of estrogen activity can be derived from the change in lipid profile levels. This indicates that lipids are closely linked to steroid hormones ${ }^{10}$. In Ethiopia, steroid hormone and lipid profile levels are not used in the diagnosis of breast cancer. Therefore, the present study was aimed to compare the serum estradiol, progesterone, and lipid profile levels between breast cancer patients and healthy controls.

\section{Materials And Methods}

A hospital-based comparative cross-sectional study was conducted at Addis Ababa University, Tikur Anbessa Specialized Hospital (TASH) from July 1/2017 to April 30/2018. Ethical clearance was obtained from the Department of Ethics and Research Committee, Department of Biochemistry, College of Health Sciences, Addis Ababa University, and informed consent was obtained from study participants. Blood samples were collected under an aseptic technique following safety procedures and the information collected from the study participants was kept confidential. A total of 80 participants ( 40 newly diagnosed breast cancer patients and 40 healthy controls) selected by convenient sampling method were enrolled in the study. The newly diagnosed breast cancer patients who were not receiving any type of treatment and age-matched healthy controls were included in the study. The study participants with diseases that can alter steroid hormones and lipid profile and pregnancy were excluded from the study. The steroid hormones and lipid profile were compared between the two groups in general and concerning age, BMI, menopausal statuses, and menstrual phases. In addition, the biochemical parameters of the two groups were compared with cut-off point values. 
The sociodemographic characteristics, clinical history, and physiological conditions were collected using a structured questionnaire. Body weight and height were measured by a digital weighing scale with a height

rod, and BMI was calculated by dividing the body weight in $\mathrm{Kg}$ by the body height in $\mathrm{m}^{2}\left(\mathrm{BMI}=\mathrm{Kg} / \mathrm{m}^{2}\right)$. Five $\mathrm{ml}$ of fasting blood sample was drawn by venipuncture and transferred to serum separator tube, and left at room temperature for $30 \mathrm{~min}$ for serum formation. The clotted blood was centrifuged at $3000 \mathrm{rpm}$ for 10 minutes and the separated serum was stored at $-80^{\circ} \mathrm{C}$ until analyses were done. Estradiol and progesterone were determined by immunoassay using fully automated Elecsys 2010 analyzer, Cobas e 411 analyzer, 2016. Lipid profile (TC, TG, LDL, and HDL-C) levels were determined by enzymatic colorimetric method using fully automated Roche/ Chemistry Cobas 6000 Analyzer ${ }^{11}$. based on the reagent manufacturer's instruction in clinical chemistry laboratory of Ethiopian public health institute.

\section{Statistical Analysis}

Statistical data were analyzed by appropriate tests using SPSS version 20.0. A simple descriptive statistics test was used to present the breast cancer risk factors and general clinical characteristics of the study participants. Categorical variables were summarized by using the number, percentage, and frequency. Continuous variables were summarized by using the mean \pm standard deviation (SD). Comparisons of the mean values between the two groups were done by independent samples t-test, and the $p$-values $<0.05$ were considered statistically significant.

\section{Results}

\section{Sociodemographic and Clinical Characteristics of the Study Participants}

A total of 80 study participants ( 40 breast cancer patients and 40 healthy controls) were enrolled in the present study. The mean age of breast cancer patients and healthy controls were $41 \pm 11.3$ and $39.6 \pm 14.6$, respectively, and did not show a significant difference between the groups $(p=0.620)$. The mean age of premenopausal status of breast cancer patients and healthy controls were $33.7 \pm 5.9$ and $28.4 \pm 4.9$ years, respectively, and showed a significant difference $(p=0.004)$. Concerning parity, most of the study participants had a child at the age of $13-25$ years. Sixty percent $(60 \%)$ of breast cancer patients were found within three months of follow-up and did not identify the type of breast cancer. All of the study participants were non-smokers, had no alcohol drinking habit and most of them did not involve in physical activity (Table 1). 
Table 1

Socio-demographic and clinical characteristics of the study participants

\begin{tabular}{|c|c|c|c|c|}
\hline \multirow[t]{2}{*}{ Variables } & \multirow[t]{2}{*}{ Classification } & \multirow{2}{*}{$\begin{array}{l}\underset{(\mathrm{NC}=40)}{\mathrm{HC}} \\
\mathrm{N}(\%)\end{array}$} & \multirow{2}{*}{$\begin{array}{l}\begin{array}{l}\mathrm{BCA} \\
(\mathrm{N}=40)\end{array} \\
\mathrm{N}(\%)\end{array}$} & \multirow[t]{2}{*}{$\begin{array}{l}\mathrm{P} \text { - } \\
\text { value }\end{array}$} \\
\hline & & & & \\
\hline \multirow[t]{3}{*}{ Age in Year } & $20-35$ & $21(52.5)$ & $13(32.5)$ & \\
\hline & $36-45$ & $3(7.5)$ & $15(37.5)$ & \\
\hline & Above 45 & $16(40)$ & $12(30)$ & \\
\hline \multicolumn{2}{|l|}{ Mean \pm SD } & $39.6 \pm 14.6$ & $41.1 \pm 11.3$ & 0.620 \\
\hline \multicolumn{2}{|l|}{ Min-max } & $20-70$ & $22-61$ & \\
\hline \multirow[t]{2}{*}{ Residence } & Urban & $34(85)$ & $26(65)$ & \\
\hline & Rural & $6(15)$ & $14(35)$ & \\
\hline \multirow[t]{6}{*}{ Region } & Addis Ababa & $10(25)$ & $11(27.5)$ & \\
\hline & Oromia & $19(47.5)$ & $12(30)$ & \\
\hline & Amhara & $6(15)$ & $9(22.5)$ & \\
\hline & Tigray & $0(0)$ & $0(0)$ & \\
\hline & SSNP & $5(12)$ & $7(17.5)$ & \\
\hline & Other & $0(0)$ & $1(2.5)$ & \\
\hline \multirow[t]{4}{*}{ Educational status } & Illiterate & $0(0)$ & 19(47.5) & \\
\hline & 1st level & $7(17.5)$ & $6(15)$ & \\
\hline & 2nd level & $7(17.5)$ & $6(15)$ & \\
\hline & Above Diplo. & $26(65)$ & $9(22.5)$ & \\
\hline \multirow[t]{4}{*}{$\mathrm{BMI}\left(\mathrm{Kg} / \mathrm{m}^{2}\right)$} & $<18$ & $7(17.5)$ & $3(7.5)$ & \\
\hline & $18-24.5$ & $29(72.5)$ & $26(65)$ & \\
\hline & $24.6-30$ & $4(10)$ & $8(20)$ & \\
\hline & $>30$ & $0(0)$ & $3(7.5)$ & \\
\hline \multicolumn{2}{|l|}{ Mean \pm SD } & $20.6 \pm 6.3$ & $22.8 \pm 4.77$ & 0.087 \\
\hline Age at 1 st menarche & After 12 & $36(90)$ & $38(95)$ & \\
\hline
\end{tabular}




\begin{tabular}{|c|c|c|c|c|}
\hline \multirow[t]{2}{*}{ Variables } & \multirow[t]{2}{*}{ Classification } & \multirow{2}{*}{$\begin{array}{l}\begin{array}{l}\mathrm{HC} \\
(\mathrm{N}=40)\end{array} \\
\mathrm{N}(\%)\end{array}$} & \multirow{2}{*}{$\begin{array}{l}\begin{array}{l}\mathrm{BCA} \\
(\mathrm{N}=40)\end{array} \\
\mathrm{N}(\%)\end{array}$} & \multirow[t]{2}{*}{$\begin{array}{l}\mathrm{P} \text { - } \\
\text { value }\end{array}$} \\
\hline & & & & \\
\hline & Before 12 & $4(10)$ & $2(5)$ & \\
\hline \multirow[t]{3}{*}{ Current monthly menstrual status } & Yes & $23(57.5)$ & $24(60)$ & \\
\hline & No & $17(42.5)$ & $16(40)$ & \\
\hline & No/chemo & & & \\
\hline \multirow[t]{3}{*}{ Phase of menstruation } & 1st and 2nd week (foll) & 19(82.6) & $13(54.2)$ & \\
\hline & $\begin{array}{l}\text { 14th day and last } \\
\text { week(lut) }\end{array}$ & $4(17.4)$ & $11(45.8)$ & \\
\hline & & $23(100)$ & $24(100)$ & \\
\hline \multirow[t]{3}{*}{ Having child } & Yes & $36(90)$ & $31(77.5)$ & \\
\hline & No & $4(10)$ & $8(20)$ & \\
\hline & Menopausal & & $1(2.5)$ & \\
\hline \multirow[t]{3}{*}{ Age at first live birth } & $13-25$ & $36(100)$ & $31(100)$ & \\
\hline & $26-35$ & $0(0)$ & $0(0)$ & \\
\hline & After 35 & $0(0)$ & $0(0)$ & \\
\hline \multirow[t]{2}{*}{ Menopausal status } & Pre & $23(57.5)$ & $24(60)$ & \\
\hline & Post & $17(42.5)$ & $16(40)$ & \\
\hline \multirow{2}{*}{$\begin{array}{l}\text { Age at menopausal status mean } \pm \\
\text { SD }\end{array}$} & Pre & $28.4 \pm 4.9$ & $33.7 \pm 5.9$ & $0.004^{\star}$ \\
\hline & Post & $54.8 \pm 7.7$ & $52.6 \pm 6$ & 0.386 \\
\hline \multirow[t]{2}{*}{ Min-max } & Pre & $20-39$ & $22-40$ & \\
\hline & Post & $45-70$ & $42-61$ & \\
\hline \multirow[t]{2}{*}{ Drinking } & Yes & $0(0)$ & $0(0)$ & \\
\hline & No & $40(100)$ & $40(100)$ & \\
\hline \multirow[t]{2}{*}{ Smoking } & Yes & $0(0)$ & $0(0)$ & \\
\hline & No & $40(100)$ & $40(100)$ & \\
\hline Exercise & Yes & $6(15)$ & $1(2.5)$ & \\
\hline $\begin{array}{l}\text { BMI }=\text { body mass index }\left(\mathrm{Kg} / \mathrm{m}^{2}\right) ; \\
\text { patients. }{ }^{*}=p-\text { value }<0.05(\text { statis } \\
\text { (standard deviation); categorical } v\end{array}$ & $\begin{array}{l}\text { breast cancer; } H C=H \epsilon \\
\text { y significant). Continuc } \\
\text { les are expressed in } n\end{array}$ & $\begin{array}{l}\text { controls, } \\
\text { ariable an } \\
\text { ers). }\end{array}$ & $\begin{array}{l}=\text { Breast } \\
\text { oressed } a\end{array}$ & $\operatorname{er} \pm S D$ \\
\hline
\end{tabular}




\begin{tabular}{|c|c|c|c|c|}
\hline \multirow[t]{2}{*}{ Variables } & \multirow[t]{2}{*}{ Classification } & \multirow{2}{*}{ 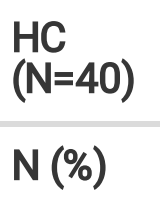 } & \multirow{2}{*}{$\begin{array}{l}\begin{array}{l}\mathrm{BCA} \\
(\mathrm{N}=40)\end{array} \\
\mathrm{N}(\%)\end{array}$} & \multirow[t]{2}{*}{$\begin{array}{l}\mathrm{P} \text { - } \\
\text { value }\end{array}$} \\
\hline & & & & \\
\hline & No & $34(85)$ & $39(97.5)$ & \\
\hline Time of identification & 3month & & $24(60)$ & \\
\hline \multirow[t]{2}{*}{ BRCA, n (\%) } & 3month-5year & & $11(27.5)$ & \\
\hline & Above 5year & & $5(12.5)$ & \\
\hline \multirow[t]{3}{*}{ Stage of disease } & I and II & & 14(35) & \\
\hline & II and V & & $11(27.5)$ & \\
\hline & Not classified & & $15(37.5)$ & \\
\hline \multirow{2}{*}{$\begin{array}{l}\text { Identification } \\
\text { of hormone level }\end{array}$} & Yes & & 0 & \\
\hline & No & & $40(100)$ & \\
\hline \multirow[t]{4}{*}{ Types of BCA } & $\mathrm{ER+}$ & & 0 & \\
\hline & PR+ & & 0 & \\
\hline & $\mathrm{ER}+$ and $\mathrm{PR}+$ & & 0 & \\
\hline & Not classified & & $40(100)$ & \\
\hline
\end{tabular}

\section{Serum Estradiol, Progesterone and Lipid Profile Levels of the Study Participants}

The biochemical analysis showed that the mean serum progesterone $(p=0.020), \operatorname{TC}(p=0.015)$, and HDL-C $(p<0.001)$ were significantly lower in breast cancer patients than in healthy controls. However, no statistically significant difference was found in the mean serum estradiol, LDL-C, and TG levels between the two groups (Table 2). 
Table 2

Serum estradiol, progesterone, and lipid profile levels of the study participants

\begin{tabular}{|llll|}
\hline Variable & $\begin{array}{l}\mathrm{HC}(\mathrm{N}=40) \\
(\text { Mean } \pm \text { SD) }\end{array}$ & $\begin{array}{l}\mathrm{BCP}(\mathrm{N}=40) \\
(\text { Mean } \pm \text { SD })\end{array}$ & p-value \\
\hline Estradiol $(\mathrm{Pg} / \mathrm{ml})$ & $70.4 \pm 72.6$ & $88.5 \pm 83.4$ & 0.304 \\
\hline Progesterone $(\mathrm{ng} / \mathrm{ml})$ & $1.68 \pm 3.3$ & $0.4 \pm 0.5$ & $0.020^{*}$ \\
\hline $\mathrm{TC}(\mathrm{mg} / \mathrm{dl})$ & $162.2 \pm 23.3$ & $145.8 \pm 34.7$ & $0.015^{*}$ \\
\hline $\mathrm{LDL}-\mathrm{C}(\mathrm{mg} / \mathrm{dl})$ & $100.9 \pm 25$ & $99.8 \pm 17.8$ & 0.823 \\
\hline $\mathrm{TG}(\mathrm{mg} / \mathrm{dl})$ & $113.1 \pm 30.5$ & $108.3 \pm 23.9$ & 0.430 \\
\hline $\mathrm{HDL}-\mathrm{C}(\mathrm{mg} / \mathrm{dl})$ & $42.6 \pm 8.5$ & $34.3 \pm 8.9$ & $<0.001^{*}$ \\
\hline SD $=$ standard deviation; HC=Healthy controls; $B C P=$ Breast cancer patients. * $=p$-value $<0.05$ \\
\hline
\end{tabular}

\section{Serum Estradiol, Progesterone and Lipid Profiles Levels of the Study Participants with the age category}

The independent samples t-test indicated that the mean serum TC and HDL-C levels were significantly lower in breast cancer patients than that of the healthy control group ( $p=0.018$ and $p=0.001)$, respectively concerning the age category of 20-30 years. In addition, for the age category of above 45 years, mean serum HDL-C level was significantly lower in breast cancer patients compared to healthy controls $(p=$ 0.007). The mean serum estradiol and progesterone levels did not show significant differences between the two groups at all age categories (Table 3 ). 
Table 3

Serum estradiol, progesterone, and lipid profile levels of the study participants with the age category

\begin{tabular}{|c|c|c|c|c|c|c|c|}
\hline $\begin{array}{l}\text { Age } \\
\text { (Yrs.) }\end{array}$ & $\begin{array}{l}\text { Study } \\
\text { Group }\end{array}$ & $\begin{array}{l}\text { Etradiol } \\
(\mathrm{pg} / \mathrm{ml})\end{array}$ & $\begin{array}{l}\mathrm{PgR} \\
\text { (ng/ml) }\end{array}$ & $\mathrm{TC}(\mathrm{mg} / \mathrm{dl})$ & $\begin{array}{l}\text { LDL-C } \\
(\mathrm{mg} / \mathrm{dl})\end{array}$ & TG (mg/dl) & $\begin{array}{l}\mathrm{HDL}-\mathrm{C} \\
(\mathrm{mg} / \mathrm{dl})\end{array}$ \\
\hline \multirow[t]{3}{*}{$\begin{array}{l}20- \\
35\end{array}$} & $\begin{array}{l}\mathrm{HC} \\
(\mathrm{N}=21)\end{array}$ & $108.6 \pm 75.9$ & $2.9 \pm 4.3$ & $162.7 \pm 19.4$ & $99.6 \pm 25.7$ & $108.7 \pm 30.5$ & $44.5 \pm 7.9$ \\
\hline & $\begin{array}{l}\mathrm{BCP} \\
(\mathrm{N}=13)\end{array}$ & $150.2 \pm 100.7$ & $0.73 \pm 0.76$ & $136.2 \pm 42.5$ & $103.6 \pm 11.8$ & $113.7 \pm 24.1$ & $34.1 \pm 8.2$ \\
\hline & $\begin{array}{l}p- \\
\text { value }\end{array}$ & 0.18 & 0.081 & $0.018^{*}$ & 0.606 & 0.618 & $0.001^{*}$ \\
\hline \multirow[t]{3}{*}{$\begin{array}{l}36- \\
45\end{array}$} & $\begin{array}{l}\mathrm{HC} \\
(\mathrm{N}=3)\end{array}$ & $93.5 \pm 66.3$ & $0.6 \pm 0.7$ & $170.7 \pm 22.2$ & $105.3 \pm 1.2$ & $102.2 \pm 23.0$ & $57.3 \pm 2.3$ \\
\hline & $\begin{array}{l}\mathrm{BCP} \\
(\mathrm{N}=15)\end{array}$ & $89.7 \pm 53.4$ & $0.3 \pm 0.2 .6$ & $157.2 \pm 28.6$ & $92.7 .9 \pm 21.4$ & $108.7 \pm 26.7$ & $38.2 \pm 10.2$ \\
\hline & $\begin{array}{l}p- \\
\text { value }\end{array}$ & 0.914 & 0.218 & 0.456 & 0.335 & 0.701 & 0.877 \\
\hline \multirow[t]{3}{*}{$\geq 45$} & $\begin{array}{l}\mathrm{HC} \\
(\mathrm{N}=16)\end{array}$ & $15.8 \pm 16$ & $0.3 \pm 0.2$ & $159.8 \pm 28.7$ & $101.7 \pm 27$ & $121.7 \pm 31.4$ & $41 \pm 9.6$ \\
\hline & $\begin{array}{l}\mathrm{BCP} \\
(\mathrm{N}= \\
12)\end{array}$ & $20 \pm 18.8$ & $0.2 \pm 1$ & $141.8 \pm 30.8$ & $104.5 \pm 16.7$ & $101.8 \pm 20$ & $31.5 \pm 6.9$ \\
\hline & $\begin{array}{l}p- \\
\text { value }\end{array}$ & 0.524 & 0.177 & 0.123 & 0.755 & 0.076 & $0.007^{\star}$ \\
\hline
\end{tabular}

Among study participants with normal BMI (18-24.5), the mean serum progesterone, TC, and HDL-C levels were significantly lower in breast cancer patients than in the healthy control group $(p=0.048),(p=0.010)$ and $(p=0.006)$, respectively. In addition, in breast cancer patients with overweight $\left(24.6-30 \mathrm{Kg} / \mathrm{m}^{2}\right)$, the mean serum progesterone $(p=0.026)$ and HDL-C $(p=0.010)$ levels were significantly lower compared to healthy controls with overweight (Table 4). 
Table 4

Serum estradiol, progesterone, and lipid profile levels of the study participants in relation to BMI

\begin{tabular}{|c|c|c|c|c|c|c|}
\hline \multirow[t]{2}{*}{ Variables } & \multicolumn{2}{|c|}{ Underweight $\left(<18 \mathrm{Kg} / \mathrm{m}^{2}\right)$} & \multirow[t]{2}{*}{ P-value } & \multicolumn{2}{|c|}{ Normal $\left(18-24.5 \mathrm{Kg} / \mathrm{m}^{2}\right)$} & \multirow[t]{2}{*}{ P-value } \\
\hline & $\mathrm{HC}(\mathrm{N}=7)$ & $\mathrm{BCP}(\mathrm{N}=3)$ & & $\mathrm{HC}(\mathrm{N}=29)$ & $\mathrm{BCP}(\mathrm{N}=26)$ & \\
\hline Estradiol (pg/ml) & $71 \pm 99$ & $10.7 \pm 6.6$ & 0.338 & $71 \pm 66.8$ & $93.8 \pm 85.2$ & 0.270 \\
\hline $\mathrm{PgR}(\mathrm{ng} / \mathrm{ml})$ & $0.4 \pm 0.6$ & $0.2 \pm 0.1$ & 0.577 & $2 \pm 3.8$ & $0.4 \pm 0.5$ & $0.048^{\star}$ \\
\hline $\mathrm{TC}(\mathrm{mg} / \mathrm{dl})$ & $156.3 \pm 24.8$ & $157.6 \pm 18.9$ & 0.938 & $165.5 \pm 23.6$ & $145.1 \pm 32.4$ & $0.010^{\star}$ \\
\hline LDL-C (mg/dl) & $100.1 \pm 36.3$ & $102.8 \pm 9.6$ & 0.905 & $103.7 \pm 22.6$ & $95.7 \pm 15.9$ & 0.137 \\
\hline TG (mg/dl) & $112.4 \pm 30$ & $105.2 \pm 2.3$ & 0.695 & $113.7 \pm 32.7$ & $106.4 \pm 27.5$ & 0.373 \\
\hline HDL-C (mg/dl) & $39.8 \pm 5.4$ & $35.1 \pm 11.3$ & 0.381 & $42.6 \pm 18.6$ & $35.6 \pm 9.6$ & $0.006^{*}$ \\
\hline \multirow[t]{2}{*}{ Variables } & \multicolumn{2}{|c|}{ Overweight(24.6-30Kg/m²) } & \multirow[t]{2}{*}{ P-value } & \multicolumn{2}{|c|}{ Obese $\left(>30 \mathrm{Kg} / \mathrm{m}^{2}\right)$} & P-value \\
\hline & $\mathrm{HC}(\mathrm{N}=4)$ & $\mathrm{BCP}(\mathrm{N}=8)$ & & $\mathrm{HC}(\mathrm{N}=0)$ & $\mathrm{BCP}(\mathrm{N}=3)$ & \\
\hline Estradiol (pg/ml) & $64.6 \pm 89.8$ & $87.7 \pm 65.5$ & 0.620 & 0 & $121.8 \pm 137$ & - \\
\hline $\mathrm{PgR}(\mathrm{ng} / \mathrm{ml})$ & $1.8 \pm 1.7$ & $0.29 \pm 0.2$ & $0.026^{*}$ & 0 & $0.83 \pm 1$ & - \\
\hline $\mathrm{TC}(\mathrm{mg} / \mathrm{dl})$ & $148.3 \pm 12.1$ & $144.1 \pm 45.6$ & 0.861 & 0 & $144.5 \pm 49.7$ & - \\
\hline LDL-C (mg/dl) & $81.73 \pm 11.5$ & $102.7 \pm 19.5$ & 0.080 & 0 & $124.8 \pm 19.8$ & - \\
\hline TG (mg/dl) & $109.8 \pm 15.9$ & $111.7 \pm 16.4$ & 0.854 & 0 & $118.7 \pm 20.7$ & - \\
\hline HDL-C (mg/dl) & $47 \pm 12.3$ & $31.8 \pm 4.9$ & $0.010^{\star}$ & 0 & $36.8 \pm 11.8$ & - \\
\hline
\end{tabular}

Statistically, a significantly lower mean serum progesterone level was found in breast cancer patients when compared to the healthy control group at premenopausal status $(p=0.015)$. Regarding lipid profile levels, significantly lower mean serum HDL-C level was observed in breast cancer patients than in healthy controls at both premenopausal $(p=0.014)$ and post-menopausal statuses $(p=0.002)$, (Table 5$)$. 
Table 5

Serum estradiol, progesterone, and lipid profile levels of study participants with menopausal statuses

\begin{tabular}{|c|c|c|c|}
\hline \multirow[t]{2}{*}{ Variables } & \multicolumn{2}{|c|}{ Premenopausal } & \multirow[t]{2}{*}{$p$-value } \\
\hline & $\mathrm{HC}(\mathrm{N}=23)$ & $\mathrm{BCP}(\mathrm{N}=24)$ & \\
\hline Estradiol pg/ml & $110 \pm 72.8$ & $134.1 \pm 78.6$ & 0.293 \\
\hline Progesterone (ng/ml) & $2.7 \pm 4.1$ & $0.57 \pm 0.61$ & $0.015^{\star}$ \\
\hline $\mathrm{TC}(\mathrm{mg} / \mathrm{dl})$ & $163.9 \pm 19.8$ & $146.3 \pm 38.6$ & 0.056 \\
\hline LDL-C (mg/dl) & $100.1 \pm 24.6$ & $97.9 \pm 18.5$ & 0.727 \\
\hline TG (mg/dl) & $109.3 \pm 29.2$ & $113 \pm 24.1$ & 0.632 \\
\hline $\mathrm{HDL}-\mathrm{C}(\mathrm{mg} / \mathrm{dl})$ & $43.9 \pm 7.7$ & $37.2 \pm 9.8$ & $0.014 *$ \\
\hline \multirow[t]{2}{*}{ Variables } & \multicolumn{2}{|c|}{ Post- menopausal } & \multirow[t]{2}{*}{$p$-value } \\
\hline & $\mathrm{N}=17$ & $\mathrm{~N}=16$ & \\
\hline Estradiol (pg/ml) & $15.9 \pm 15.6$ & $20.1 \pm 17.1$ & 0.473 \\
\hline Progesterone (ng/ml) & $0.27 \pm 0.21$ & $0.2 \pm 0.09$ & 0.218 \\
\hline $\mathrm{TC}(\mathrm{mg} / \mathrm{dl})$ & $159.8 \pm 27.8$ & $145 \pm 29.1$ & 0.145 \\
\hline LDL-C (mg/dl) & $101.9 \pm 26.1$ & $102.6 \pm 16.8$ & 0.925 \\
\hline TG (mg/dl) & $118.3 \pm 32.2$ & $101.9 \pm 26.1$ & 0.086 \\
\hline HDL-C (mg/dl) & $40.8 \pm 9.3$ & $31.4 \pm 6.1$ & $0.002^{*}$ \\
\hline
\end{tabular}

Independent samples t-test showed that the mean serum progesterone and HDL-C levels of the breast cancer patients were significantly lower as compared to healthy controls at the follicular phase $(p=0.022$ and $p=0.001$ ), respectively. At the luteal phase, significantly lower mean serum progesterone level was observed in breast cancer patients than in healthy controls $(p=0.009)$, (Table 6$)$. 
Table 6

Serum estradiol, progesterone, and lipid profile levels of the study participants with menstrual phases

\begin{tabular}{|c|c|c|c|}
\hline \multirow[t]{2}{*}{ Variables } & \multicolumn{2}{|c|}{ Follicular phase } & \multirow[t]{2}{*}{ P-value } \\
\hline & $\mathrm{HC}(\mathrm{N}=19)$ & $\mathrm{BCP}(\mathrm{N}=13)$ & \\
\hline Estradiol (pg/ml) & $111.7 \pm 73.3$ & $114.2 \pm 49.6$ & 0.918 \\
\hline Progesterone (ng/ml) & $1.68 \pm 2$ & $0.3 \pm 0.17$ & $0.022^{*}$ \\
\hline TC (mg/dl) & $164.1 \pm 20.9$ & $143 \pm 41.2$ & 0.065 \\
\hline LDL-C (mg/dl) & $100.6 \pm 26.7$ & $102.1 \pm 11.5$ & 0.856 \\
\hline $\mathrm{TG}(\mathrm{mg} / \mathrm{dl})$ & $109.1 \pm 29.1$ & $114 \pm 25.5$ & 0.634 \\
\hline HDL-C (mg/dl) & $43.6 \pm 7.6^{a}$ & $33.6 \pm 7.1$ & $0.001^{*}$ \\
\hline \multirow[t]{2}{*}{ Variables } & \multicolumn{2}{|l|}{ Luteal phase } & P-value \\
\hline & $\mathrm{N}=4$ & $\mathrm{~N}=11$ & \\
\hline Estradiol (pg/ml) & $105 \pm 80.8$ & $157.6 \pm 100.7$ & 0.367 \\
\hline Progesterone $(\mathrm{ng} / \mathrm{ml})$ & $7.7 \pm 7.8$ & $0.87 \pm 00.8$ & $0.009^{*}$ \\
\hline TC (mg/dl) & $163 . \pm 16.1$ & $150.2 \pm 36.8$ & 0.521 \\
\hline LDL-C (mg/dl) & $97.8 \pm 12.3$ & $93 \pm 24.1$ & 0.713 \\
\hline $\mathrm{TG}(\mathrm{mg} / \mathrm{dl})$ & $109.7 \pm 34.3$ & $111.9 \pm 23.5$ & 0.888 \\
\hline $\mathrm{HDL}-\mathrm{C}(\mathrm{mg} / \mathrm{dl})$ & $45.1 \pm 10.3$ & $41.4 \pm 11.2$ & 0.578 \\
\hline
\end{tabular}

Serum Estradiol, Progesterone and Lipid Profile Levels among Study Participants Compared to Cut-off Points

Regarding the abnormality of the study parameters, $62.5 \%$ and $72.5 \%$ of the breast cancer patients showed lower mean serum progesterone and HDL-C levels, respectively as compared to reference range /cut-off points. These abnormalities were only $5 \%$ and $10 \%$ for healthy controls (Table 7 ). 
Table 7

Percentage of breast cancer patients and healthy controls with abnormal levels of serum steroid hormones and lipid profile

\begin{tabular}{|c|c|c|c|c|c|}
\hline \multirow[t]{2}{*}{ Variables } & \multirow[t]{2}{*}{ Menopausal Status } & \multirow[t]{2}{*}{$\begin{array}{l}\text { Ovulation } \\
\text { Phase }\end{array}$} & \multirow[t]{2}{*}{$\begin{array}{l}\text { Cut-off } \\
\text { points }\end{array}$} & $\begin{array}{l}\mathrm{HC} \\
(\mathrm{N}=40)\end{array}$ & $\begin{array}{l}\mathrm{BCP} \\
(\mathrm{N}=40)\end{array}$ \\
\hline & & & & $\mathbf{N}(\%)$ & $N(\%)$ \\
\hline \multirow[t]{7}{*}{ Estradiol $(\mathrm{pg} / \mathrm{ml})$} & \multirow[t]{5}{*}{$\begin{array}{l}\text { Pre-menopausal } \\
\text { status }\end{array}$} & $\begin{array}{l}\text { Follicular } \\
\text { phase }\end{array}$ & $\geq 232.5$ & $1(2.5)$ & $4(10)$ \\
\hline & & \multirow[t]{4}{*}{ luteal phase } & $\leq 12.35$ & 0 & $1(2.5)$ \\
\hline & & & $\geq 397$ & 0 & $3(7.5)$ \\
\hline & & & $\leq 22.28$ & 0 & 0 \\
\hline & & & $\geq 136$ & 0 & 0 \\
\hline & \multicolumn{2}{|l|}{ Post-menopausal } & $\leq 5$ & 0 & 0 \\
\hline & Total & & & $1(2.5)$ & 7 (17.5) \\
\hline \multirow{7}{*}{$\begin{array}{l}\text { Progesterone } \\
(\mathrm{ng} / \mathrm{ml})\end{array}$} & \multirow{4}{*}{$\begin{array}{l}\text { Pre-menopausal } \\
\text { status }\end{array}$} & \multirow{2}{*}{$\begin{array}{l}\text { Follicular } \\
\text { Phase }\end{array}$} & $\geq 1.4$ & $2(5)$ & 0 \\
\hline & & & $\leq 0.2$ & 0 & $4(10)$ \\
\hline & & \multirow[t]{2}{*}{ luteal phase } & $\geq 2.7$ & $3(7.5)$ & 0 \\
\hline & & & $\leq 0.8$ & 0 & $14(35)$ \\
\hline & \multirow[t]{2}{*}{ Post-menopausal } & & $\geq 0.8$ & 0 & 0 \\
\hline & & & $\leq 0.1$ & 0 & $7(17.5)$ \\
\hline & Total & & & $5(12.5)$ & $25(62.5)$ \\
\hline $\mathrm{TC}(\mathrm{mg} / \mathrm{dl})$ & & & $\geq 200$ & $2(5)$ & $2(5)$ \\
\hline LDL-C (mg/dl) & & & $\geq 129$ & $2(5)$ & $7(17.5)$ \\
\hline $\mathrm{TG}(\mathrm{mg} / \mathrm{dl})$ & & & $\geq 200$ & $1(2.5)$ & $3(7.5)$ \\
\hline $\mathrm{HDL}-\mathrm{C}(\mathrm{mg} / \mathrm{dl})$ & & & $<40$ & $10(25)$ & $29(72.5)$ \\
\hline
\end{tabular}

\section{Discussion}

Steroid hormones (estrogen and progesterone) play a major role in the etiology of breast cancer (8). An excess free serum estrogen level is responsible for the high rate of immature cell replication and increased fat metabolism in the body ${ }^{12}$. The present study assessed the serum level of estradiol, progesterone, and lipid profile (TC, LDL-C, TG, and HDL-C) of the study participants. The biochemical parameters were compared between breast cancer patients and healthy controls by considering different associated factors such as sociodemographic characteristics, parity, menstrual phases, menopausal statuses, and BMI. The biochemical parameters of the study participants were also compared with normal reference ranges. 
The results of this study showed that the mean serum progesterone levels were lower in breast cancer patients than in healthy controls in general and specifically with normal BMI, overweight, premenopause, and both menstrual phases. Previous studies done by Houghton et al., Hussain et al., and Kaaks et al., are in agreement with this study results ${ }^{13-15}$. Saez et al. also proposed that a low progesterone /estrogen ratio and ovulatory cycles are more frequent in breast cancer patients than in a normal population and suggested that a relatively low progesterone secretion might favor the development of cancer ${ }^{16}$. However, Ho et al., reported that in postmenopausal women serum progesterone levels were significantly associated positively with the chances of having breast cancer ${ }^{17}$. On the contrary, Yu et al. did not find any significant difference in progesterone level between cancer patients and healthy controls of Chinese premenopausal women ${ }^{18}$. In addition, Missmer et al. also reported no significant association between the breast cancer risk and the progesterone levels ${ }^{19}$.

The reduction in progesterone level in the present study may be due to the ovarian hyperandrogenism hypothesis/ luteal inadequacy hypothesis, which states ovarian androgen excess, chronic anovulation, and an associated reduction of luteal phase progesterone production ${ }^{15}$. The other reason could be due to a decrease in TG, LDL-C, and HDL-C concentrations in breast cancer patients. Because HDL-C and LDL-C may serve as the source of cholesterol in steroidogenesis ${ }^{20}$. An additional justification is that the elevation level of estradiol can block ovulation, and may cause stress. Stress in turn increases the release of cortisol that decreases sex hormone-binding globulin (SHBG) and this leads to an increase in free estrogen level and decreased production of progesterone. The cortisol is responsible for the increase in the production of cortisol binding globulin that deactivates free progesterone in plasma by its binding activity 21 .

Serum estradiol levels were insignificantly higher in breast cancer patients than that of healthy controls in general as well as for breast cancer risk factors, including age, BMI, menopausal statuses, and menstrual phases. These results are supported by the study results of Farhat et al., Trehan et al., and Blair ${ }^{22-24}$. In contrast to the current study results, Hussain et al. stated that breast cancer patients showed a lower level of estrogen when compared with healthy controls ${ }^{14}$. This could probably be due to the failure of proper matching between the cases and the controls concerning their different phases of the menstrual cycle during the measurements of the blood hormone. In addition, Abdelhadi reported no significant difference in the serum estrogen levels between the control subjects and the breast cancer patients of Sudanese women 25. Yu et al. and Awio et al. also suggested that there was no significant association between the estradiol level and breast cancer among Ugandan and Chinese women, respectively ${ }^{18,26}$. This contradiction may be due to the circulating levels of estrogen in premenopausal women, which is not only differ significantly from person to person but also vary substantially throughout the menstrual cycle. The less-stringent matching conditions on menstruation days may also hamper the ability to detect any significant difference in estrogen levels between the study groups.

The reason for the elevation of serum estradiol in the present study may be due to increased endogenous production of aromatase /overexpression of aromatase activity in extra ovarian tissues and within the tumor tissue ${ }^{27-29}$. The other reasons may be the low concentration of SHBG that occurs in breast cancer 
patients, deficiency of vitamins like B, E, minerals like magnesium, and substance like indole 3-carbinol that may affect estrogen metabolism and increase free estrogen levels in the bloodstream ${ }^{21}$.

The evaluation of serum lipid profile levels revealed that the mean serum TC levels were significantly lower in breast cancer patients compared with the healthy control group in general and particularly for the age category of 20-35 years and normal BMI. The results are in line with the study results of Li et al., Kshirsagar et al., Mishra, and Asegaonkar et al. ${ }^{30-33}$. In contrast to our study results, Guan et al., Pandeya et al., Raza et al., Rohariya et al., and Nayak et al. indicated that an increase in TC levels was observed in breast cancer patients when compared to healthy controls ${ }^{34-38}$. Interestingly, some studies reported TC levels were not significantly different between breast cancer patients and healthy control group ${ }^{39-41}$.

The lowering of TC levels in breast cancer patients may be explained by the fact that there was a higher amount of estradiol and a lower amount of progesterone hormones in the serum of the breast cancer patients. The increased estradiol concentrations promote the activity of the hepatic triglyceride lipase (HTGL) enzyme and consequently decreases the synthesis of TC. The lowered concentrations of progesterone influence the action of estradiol on the lipid profile of the breast cancer patients ${ }^{42}$. Perhaps, the enhancement of cholesterol utilization by neoplastic cells for new membrane biogenesis during cell proliferation might also have increased the catabolism of cholesterol and decreased cholesterol synthesis ${ }^{32}$. Another reason could be due to the lowering of progesterone concentration with excess androgenic effect on breast cancer patients.

The serum HDL-C levels were found to be significantly lower in breast cancer patients than in healthy controls. These phenomena were observed with the age category of 20-35 and above 45, normal BMI, and overweight, as well as at both menopausal statuses and follicular phase of the menstrual cycle. Our study results are supported by previously reported study results by Li et al., Kshirsagar et al., Pandeya et al., Raza et al., and Zhao et al. ${ }^{30,31,35,37,39}$. Llanos et al. also reported that high levels of HDL-C were inversely associated with breast cancer among African-American women ${ }^{43}$. In addition, Kshirsagar et al. revealed that low HDL-C levels may be associated with an increased risk of breast cancer ${ }^{31}$. The decrease in HDL-C levels in breast cancer patients may be due to the lowering of serum TC level, because HDL-C may reverse transport of cholesterol ${ }^{35}$. Although, maybe associated with lowering of progesterone in relation to excess androgenicity effect on breast cancer patients, that is associated with high levels of free biologically active estradiol. The consequences of excess estradiol level without controlling of progesterone decrease the LPL activity and reduce the production of HDL-C ${ }^{9}$

Contrary to the above observations, Peela et al. reported significantly elevated serum HDL-C in breast cancer patients when compared to healthy controls ${ }^{44}$. Martin et al. also found that the serum HDL-C was positively associated with a higher risk of breast cancer ${ }^{40}$. On the other hand, the results of some researchers like Guan et al., Rohariya et al., Laisupasin et al., and Abdelsalam, et al. indicated that there were no significant differences between HDL-C levels between breast cancer patients and healthy control group $34,36,45,46$. Concerning the TG and LDL-C levels, no significant difference was observed between the breast cancer patients and healthy controls. 
In the current study, the assessment of abnormality of mean serum estradiol, progesterone, and lipid profile levels of breast cancer patients and healthy controls was compared with reference range /cut off points. Accordingly, in breast cancer patients, except TC and LDL-C, the levels of measured parameters showed higher abnormality compared to reference range /cut off points. Markedly, $62.5 \%$ and $72.5 \%$ of the breast cancer patients exhibited lower progesterone and HDL-C levels, respectively compared to cut-off points. All of the $62.5 \%$ progesterone abnormality in breast cancer patients was observed in premenopause. Our results are supported by Flote et al. ${ }^{47}$. The main reason for the abnormality of progesterone may be due to estrogen (estradiol) dominance in breast cancer patients ${ }^{(21)}$. Another justification could be the ovarian hyperandrogenism hypothesis associated reduction of luteal phase progesterone production ${ }^{15}$ excess estradiol may leads to lower serum TC, LDL-C and HDL-C which required for production of progesterone 20 . In addition, estrogen-induced cortisol levels can decrease sex hormone binding-globulin and increase corticosteroid-binding globulin, which leads to progesterone deactivation ${ }^{21}$. The possible mechanisms responsible for the abnormality of HDL-C level in breast cancer patients could be; i. the reduction of TC level as the result of an increase in neoplastic transformation of the cancer cells ${ }^{35}$, 41 ; ii inactivation of the lipolytic enzymes (lipoprotein lipase and hepatic lipoprotein lipase) 9,48 and iii. the absence of sufficient quantities of progesterone that can lead the body to make androgens to regulate the effect of estrogen ${ }^{42}$.

\section{Conclusions}

The findings of the current study revealed that the mean serum progesterone, TC, and HDL-C levels were significantly lowered in breast cancer patients when compared with healthy controls. On the other hand, the mean serum estradiol levels were insignificantly higher among breast cancer patients than healthy controls. Whereas, insignificantly lower mean serum LDL-C and TG levels were observed in breast cancer patients when compared with the healthy control group. Therefore, breast cancer might be responsible for the abnormal changes in steroid hormones and lipid profile regardless of the associated risk factors that could alter the biochemical levels and could lead to the development of secondary complications. Thus, we recommend that the steroid hormones and lipid profile tests should be included in the diagnosis of breast cancer.

\section{Abbreviations}

ANOVA

Analysis of variance

BMI

Body Mass Index

ER+

Estrogen Receptor-Positive

$\mathrm{PR}+$

Progesterone Receptor-Positive

HDL-C

High-Density Lipoprotein Cholesterol 
LDL-C

Low-Density Lipoprotein Cholesterol

TG

Triglyceride

TC

Total Cholesterol

\section{Declarations}

\section{Ethics approval and consent to participate}

The ethics permission and consent to participate was granted from Departmental Ethics and Research Committee (DRERC) of Addis Ababa University. Furthermore, each study participant provided written informed consent at the time of data collection. After obtaining full informed consent, data collection began. Throughout the course of this investigation, all information received from study participants was kept strictly secret.

Consent for publication: N/A

\section{Availability of data and materials}

All necessary data and materials related to the article are included in the manuscript, and supporting data can be obtained from the authors when necessary.

\section{Competing interests}

The authors declare that they have no competing interests.

\section{Funding}

The research was funded by Addis Ababa University. The funder had no role in designing the study, collection, analysis, and interpretation of data as well as the writing of the manuscript.

\section{Authors' contribution}

ET, DS, MM, and WT conceived, designed the study, and analyzed and interpreted the data. MM, TOF and $\mathrm{BN}$ are involved in data acquisition, analysis, and result interpretations. All the authors read, commented on, and contributed to the submitted manuscript.

\section{Acknowledgments}

We are extremely grateful to Addis Ababa University for funding the research and the Department of Biochemistry, Addis Ababa University, for its indispensable support and coordination in the smooth running of this project, We would also like to express our deepest gratitude to the study participants, Ms. Ture 
Girma, Ms. Bethlehem Tefera and nursing staff of Oncology, Addis Ababa University for their direct and indirect contribution to the study.

\section{References}

1. Bray F, Ferlay J, Soerjomataram I, Siegel RL, Torre LA, Jemal A. Global cancer statistics 2018: GLOBOCAN estimates of incidence and mortality worldwide for 36 cancers in 185 countries. Cancer J Clin. 2018;68(6):394-424.

2. Ali LO. Study effect of breast cancer on some hematological and biochemical parameters in Babylon Province, Iraq. IOSR (IOSR-JPBS). 2014;9(3):20-4.

3. Chauhan P, Yadav R, Kaushal V, Beniwal P. Evaluation of serum biochemical profile of breast cancer patients. International Journal of Medical Research Health Sciences. 2016;5(7):1-7.

4. Shah R, Rosso K, Nathanson SD. Pathogenesis, prevention, diagnosis, and treatment of breast cancer. World J Clin Oncol. 2014;5(3):283.

5. Brinton LA, Figueroa JD, Awuah B, Yarney J, Wiafe S, Wood SN, et al. Breast cancer in Sub-Saharan Africa: opportunities for prevention. Breast cancer research treatment. 2014;144(3):467-78.

6. Abate S, Yilma Z, Assefa M, Tigeneh W. Trends of breast cancer in Ethiopia. Int J Cancer Res Mol Mech. 2016;2(1):1.

7. Hadgu E, Seifu D, Tigneh W, Bokretsion Y, Bekele A, Abebe M, et al. Breast cancer in Ethiopia: evidence for a geographic difference in the distribution of molecular subtypes in Africa. BMC Womens Health. 2018;18(1):1-8.

8. Buijs $\mathrm{C}$, de Vries EG, Mourits MJ, Willemse PH. The influence of endocrine treatments for breast cancer on health-related quality of life. Cancer treatment reviews. 2008;34(7):640-55.

9. Shah FD, Shukla SN, Shah PM, Patel HR, Patel PS. Significance of alterations in plasma lipid profile levels in breast cancer. Integrative cancer therapies. 2008;7(1):33-41.

10. Pecks U, Rath W, Kleine-Eggebrecht N, Maass N, Voigt F, Goecke T, et al. Maternal serum lipid, estradiol, and progesterone levels in pregnancy, and the impact of placental and hepatic pathologies.

Geburtshilfe Frauenheilkd. 2016;76(7):799.

11. HDL-C LDL-C. TG, Cholesterol - Cobas c501/c502, Lab-4287, Lab-4455, Lab-4285, (cobas, 2016).

12. Feigelson HS, Henderson BE. Estrogens and breast cancer. Carcinogenesis. 1996;17(11):2279-84.

13. Houghton LC, Ganmaa D, Rosenberg PS, Davaalkham D, Stanczyk FZ, Hoover RN, et al. Associations of breast cancer risk factors with premenopausal sex hormones in women with very low breast cancer risk. Int J Environ Res Public Health. 2016;13(11):1066.

14. Hussain D, Ahmed S, Hoque M, Rabbi S, Masood S, Shafi T, et al. Biochemical factors associated with breast cancer in Bangladeshi women. Bangladesh Journal of Medical Biochemistry. 2013;6(2):58-62.

15. Kaaks R, Berrino F, Key T, Rinaldi S, Dossus L, Biessy C, et al. Serum sex steroids in premenopausal women and breast cancer risk within the European Prospective Investigation into Cancer and Nutrition (EPIC). J Natl Cancer Inst. 2005;97(10):755-65. 
16. Saez S, Martin PM, Chouvet CD. Estradiol and progesterone receptor levels in human breast adenocarcinoma in relation to plasma estrogen and progesterone levels. Can Res. 1978;38(10):346873. 16.

17. Ho C, Rohaizak M, Zulkifli S, Siti-Aishah M, Nor-Aini U, Sharifah-Noor-Akmal S. Serum sex hormone levels in pre-and postmenopausal breast cancer patients. Singapore medical journal. 2009;50(5):513.

18. Yu H, Shu XO, Shi R, Dai Q, Jin F, Gao YT, et al. Plasma sex steroid hormones and breast cancer risk in Chinese women. International journal of cancer. 2003;105(1):92-7.

19. Missmer SA, Eliassen AH, Barbieri RL, Hankinson SE. Endogenous estrogen, androgen, and progesterone concentrations and breast cancer risk among postmenopausal women. J Natl Cancer Inst. 2004;96(24):1856-65.

20. Miller JB, McLean MP. Evidence for the preferential utilization of esterified cholesterol in progesterone production by rabbit corpora lutea. Biol Reprod. 1987;36(3):729-39.

21. Taylor EB, Bell-Taylor A. Are your hormones making you sick? A Woman's Guide to Better Health through Hormone Balance. 3rd ed. US: Physicians Natural Medicine Inc.; 2003.

22. Farhat GN, Parimi N, Chlebowski RT, Manson JE, Anderson G, Huang AJ, et al. Sex hormone levels and risk of breast cancer with estrogen plus progestin. J Natl Cancer Inst. 2013;105(19):1496-503.

23. Trehan AS, Arora MK, Seth S, Chauhan A. Endogenous hormones in postmenopausal females with breast cancer-before and after treatment. Clinical laboratory. 2012;58(7-8):771-7.

24. Blair IA. Analysis of estrogens in serum and plasma from postmenopausal women: past present, and future. Steroids. 2010;75(4-5):297-306.

25. Abdelhadi H, Sirelkhatim D, Eltayeb E, Ahmed W, Elhussein B. Levels of estrogen, carcinoembryonic antigen and cancer antigen of breast in Sudanese female with breast cancer. 2006.

26. Awio JP, Galukande M, Kituuka O, Fualal JO. High serum estradiol confers no risk for breast cancer: another disparity for sub-Saharan Africa women. Pan African Medical Journal. 2012;12(1).

27. Santen R, Yue W, Naftolin F, Mor G, Berstein L. The potential of aromatase inhibitors in breast cancer prevention. Endocr Relat Cancer. 1999;6(2):235-43.

28. Bulun SE, Chen D, Moy I, Brooks DC, Zhao H. Aromatase, breast cancer and obesity: a complex interaction. Trends in Endocrinology Metabolism. 2012;23(2):83-9.

29. Cleary MP, Grossmann ME. Obesity and breast cancer: the estrogen connection. Endocrinology. 2009;150(6):2537-42.

30. Li X, Liu Z-I, Wu Y-t, Wu H, Dai W, Arshad B, et al. Status of lipid and lipoprotein in female breast cancer patients at initial diagnosis and during chemotherapy. Lipids Health Dis. 2018;17(1):91.

31. Kshirsagar VV, Vaze DD, Dhamane BK, Seema G, Prasanna A, Yawalkar P. Pratinidhi SA. Comparative Study of Lipid Profile in Patients with Carcinoma Breast Attending a Tertiary Care Hospital of Western Maharashtra. International Journal Contemporary Medical Research. 2016;3(4):1093-5.

32. Mishra S. Lipid profile in breast cancer patients. International Journal of Pharmaceutical Medical Research. 2015;3(1):29-35. 
33. Asegaonkar S, Chaudhari S, Bardapurkar J. Lipid profile in breast cancer patients from rural India. J Indian Med Assoc. 2012;110(11):831-2, 7.

34. Guan X, Liu Z, Zhao Z, Zhang X, Tao S, Yuan B, et al. Emerging roles of low-density lipoprotein in the development and treatment of breast cancer. Lipids Health Dis. 2019;18(1):1-9.

35. Pandeya DR, Rajbhandari A, Nepal M, Abdalhabib EK, Bhatta M, Malla SS, et al. Comparative Study of Serum Lipid Profiles in Nepalese Cancer Patients Attending a Tertiary Care Hospital. Asian Pacific journal of cancer prevention: APJCP. 2018;19(2):491.

36. Rohariya $\mathrm{H}$, Gharde $\mathrm{P}$, Gharde PM. Lipid profile and its relevance in carcinoma breast. International Surgery Journal. 2017;4(7):2227-32.

37. Raza U, Asif MR, Rehman AB, Sheikh A. Hyperlipidemia and hyperglycemia in Breast Cancer Patients is related to disease stage. Pakistan journal of medical sciences. 2018;34(1):209.

38. Nayak SR, Rao GB, Soren DK, Kiran J. Lipid Profile in Newly Detected Carcinoma Breast Patients: A Tertiary Institutional Study. IJSS Journal of Surgery. 2016;2(2):43-6.

39. Zhao Y, Wang H, Pan Y, Li N, Bian C. Association of lipid profile levels in premenopausal and postmenopausal women with breast cancer: a meta-analysis. Int J Clin Exp Med. 2016;9(2):552-63.

40. Martin LJ, Melnichouk O, Huszti E, Connelly PW, Greenberg CV, Minkin S, et al. Serum lipids, lipoproteins, and risk of breast cancer: a nested case-control study using multiple time points. JNCl: Journal of the National Cancer Institute. 2015;107(5).

41. Abas AM, Zaki HY, Faggad A, Alhaj AM, Abdalla BE. Lipid profiles of Sudanese cancer patients. Sudan Medical Journal. 2014;11(2254):1-14.

42. Callejon DR, Rios D, Franceschini SA, Toloi M. Transdermal estradiol and lipid profile: effects on a specific group of Brazilian postmenopausal women. Arq Bras Cardiol. 2009;93(6):571-5.

43. Llanos AA, Makambi KH, Tucker CA, Wallington SF, Shields PG, Adams-Campbell LL. Cholesterol, lipoproteins, and breast cancer risk in African-American women. Ethn Dis. 2012;22(3):281.

44. Peela J, Jarari A, El Saiety S, El Busaifi S, El Awamy H, Srikumar S. The relationship between serum lipids and breast cancer in Libya. Biochem Anal Biochem. 2012;1(6):1-3.

45. Laisupasin P, Thompat W, Sukarayodhin S, Sornprom A, Sudjaroen Y. Comparison of serum lipid profiles between normal controls and breast cancer patients. Journal of laboratory physicians. 2013;5(1):38.

46. Abdelsalam KEA, Hassan IK, Sadig IA. The role of developing breast cancer in alteration of serum lipid profile. Journal of research in medical sciences: the official journal of Isfahan University of Medical Sciences. 2012;17(6):562.

47. Flote VG, Frydenberg H, Ursin G, Iversen A, Fagerland MW, Ellison PT, et al. High-density lipoproteincholesterol, daily estradiol and progesterone, and mammographic density phenotypes in premenopausal women. Cancer prevention research. 2015;8(6):535-44.

48. Furberg A-S, Jasienska G, Bjurstam N, Torjesen PA, Emaus A, Lipson SF, et al. Metabolic and hormonal profiles: HDL cholesterol as a plausible biomarker of breast cancer risk. The Norwegian EBBA Study. Cancer Epidemiology Prevention Biomarkers. 2005;14(1):33-40. 